第 8 表 筑波山項午前 6 時氣溫が 24 時間に5 度以上變化した回数之風向變化角庭（24 時間內）との關㛊

\begin{tabular}{c|r|r|r|r|r|r|r|r|r|r|r}
\hline 年 & 1922 & 1923 & 1924 & 1925 & 1926 & 1927 & 1928 & 1929 & 1930 & 1931 & 合諳十 \\
\hline 0 & 5 & 2 & 3 & 5 & 4 & 7 & 7 & 6 & 11 & 4 & 54 \\
$\pi / 8$ & 7 & 12 & 7 & 6 & 3 & 4 & 10 & 6 & 4 & 5 & 64 \\
$\pi / 4$ & 9 & 7 & 10 & 3 & 12 & 10 & 7 & 7 & 5 & 5 & 75 \\
$3 \pi / 8$ & 7 & 8 & 5 & 10 & 9 & 10 & 6 & 6 & 4 & 10 & 75 \\
$\pi / 2$ & 5 & 6 & 5 & 1 & 5 & 3 & 6 & 10 & 7 & 8 & 56 \\
$5 \pi / 8$ & 13 & 10 & 3 & 6 & 2 & 9 & 6 & 7 & 1 & 6 & 63 \\
$3 \pi / 4$ & 7 & 9 & 8 & 8 & 6 & 3 & 4 & 7 & 8 & 8 & 68 \\
$7 \pi / 8$ & 7 & 12 & 7 & 2 & 1 & 3 & 4 & 5 & 6 & 11 & 58 \\
$\pi$ & 1 & 3 & 1 & 1 & 1 & 4 & 2 & 5 & 1 & 3 & 22 \\
\hline
\end{tabular}

1 月, 3 月に多く起り 5 月, 6 月, 7 月, 8 月, 9 月 に少なく且つ又朝 6 時と翌朝 6 特との風向の䬤堂ひが $\frac{\pi}{4}, \frac{3}{4} \pi$ なる時に多く起り $0, \frac{\pi}{2}$ なる時には少ない樣 な結果となつたが之は各々の平均頻度に對する比を求
めねは確かな事は分らない。

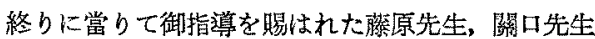
に檿く感謝致します。

本邦各地の降水量の調和解析*

中原孫吉

\section{\$1. 䦃言}

本邦降水量の䂰究に關しては中央氣象亨長岡四先生 の研究，其他多數あり. 本調查は 76 r所の測俟所の 觀測成績の累年本均降水量に就いて調和解析を試之 た. 氣溫と異り降水量の解析結果は複雜である。降水 は地理的閣係より考ふれば地形の影響が多く，海拔高 或は緯度と密接な關倸がある。市大部分の地方は梅

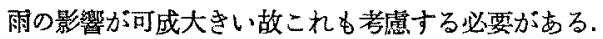

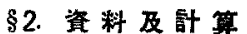

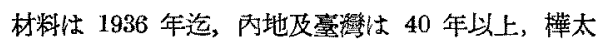
は 25 年以上，朝鮮は 20 年以上觀测資料の方る總計 76 の測候所の觀測成績の累年平均值を用ひた。

計算方法は，降水量 $R$ を通日を角度で表はした $r$ の函數と見て

$R=a_{0}+a_{1} \sin \left(r+\varphi_{1}\right)+a_{2} \sin \left(2 r+\varphi_{2}\right)+a_{3} \sin \left(3 r+\varphi_{3}\right)$

$$
+a_{1} \sin \left(4 r+\varphi_{8}\right)+a_{5} \sin \left(5 r+\varphi_{5}\right)
$$

と就き， $a_{0}, a_{1}, a_{2}, c_{3}, \varphi_{1}, \varphi_{2}, \varphi_{3}$ 等を求めた. 第 1 表 はそれ等の數值を示士．調和解析には便宜上月平均降 水量を以てし，諨算に先ち2月の降水量には 1.07 を 又31 日ある大の月には 097 を乘じ30日を一個月の 日數とするbのと同格になるやうに算した， $a_{4}, a_{5}$, $\varphi_{3} . \varphi_{4}$ 等す看遁せない位大きかつたので算出した。倘 $r$ の原战は 1 月 15 日にとつた.

\section{\$3. 各监化の振幅の大さ}

氣溫の調和解析には第 1 項と共に第 2 項䄪ち年變 化が主要項で他は振幅が徽少であるが降水量に於ては 趣を異にする．何れの項が年變化に次いで大いか，そ の割合を見るため年督化の振幅 $u_{1}$ に對する他の振幅 $a_{2}, a_{3}, a_{4}, a_{5}$ 等の割合を各地方別に調べたが第 1 圖に 示す如く I-VII の 7 種類に分類出來た. $a$ 又 $b$ を 附したのは其小區分を示す，その各類に垉する場所は 第 2 表の通りである. 所喰場所の數から云つて多い のは II, $\mathrm{I}_{a}, \mathrm{I}_{b}, \mathrm{III}_{a}$ で IV 相賞あるが V,VI は非 常に越く，VII は不垣島，IIIは弗䩴にの子見られ ๖.

Ia は本州では中部地方以東, 朝鮮では中部以北,

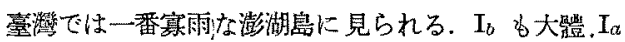
と同地方でるが，北海道, 樺太,臺灣及び朝焦の北部 に多い.

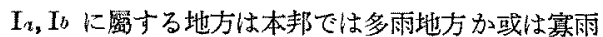
地方である。

II, IIIn,IIIは殆んど中部地方以西である.IVは

* M. Nakahara: On the Fourier's Coefficient for Rainfall and their Geographical Distributions in Japan. 


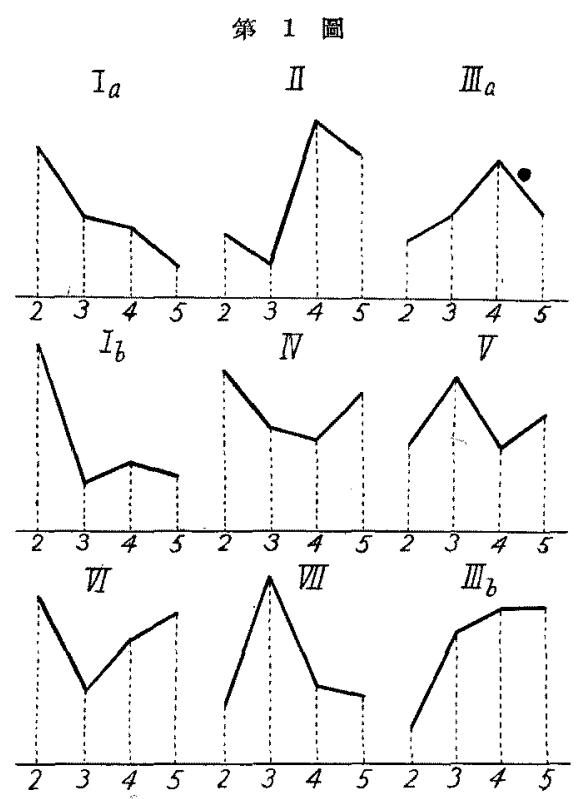

も大ならず，文場所によつては $\frac{1}{4}$ 或は $\frac{1}{5}$ 年變化が 大い事が分る。

\section{\$4. 年俆化}

年變化の振幅 $a_{1}$ は第 1 表に示す. $R$ の年較差は 銚子を除いては主として此の項に由る，又場所によつ ては他の項怯影響ない位小さい，第2 渭佶 $a_{1}$ の分布 を示す， $a_{1}$ の最大值は㗌灣の恒春，最小值は網走汇あ

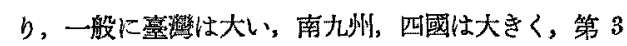

名古屋は例外であるが, 多くは北海道, 樺太, 朝鮮南 部に多い，之によつて年變化に次いで牛年變化必ずし

第 2 涌 $a_{1}$ 公分布圖

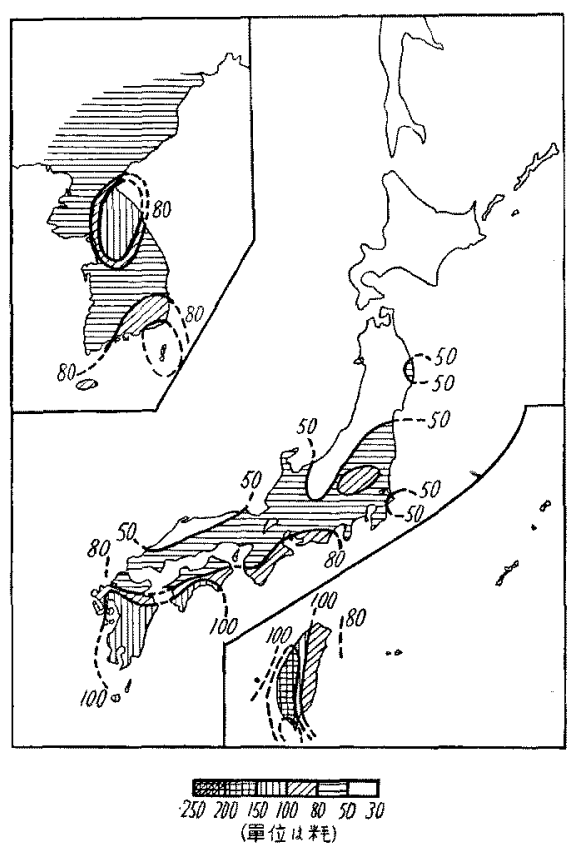

第 3 圆

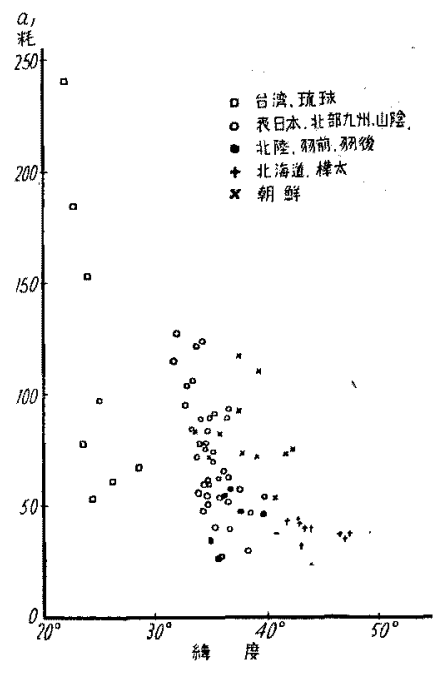

第 4 圆

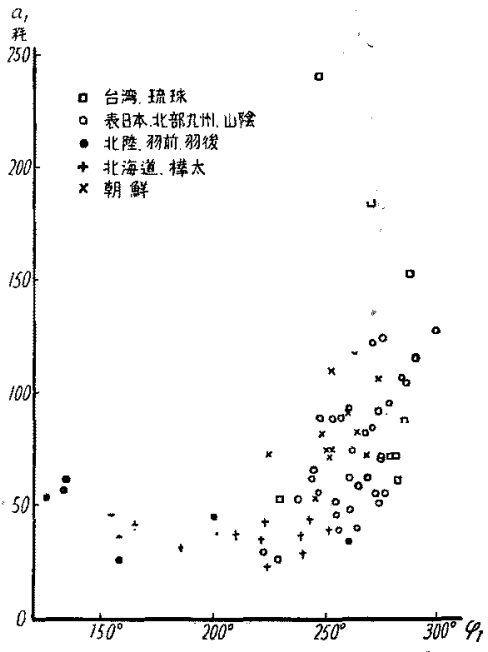




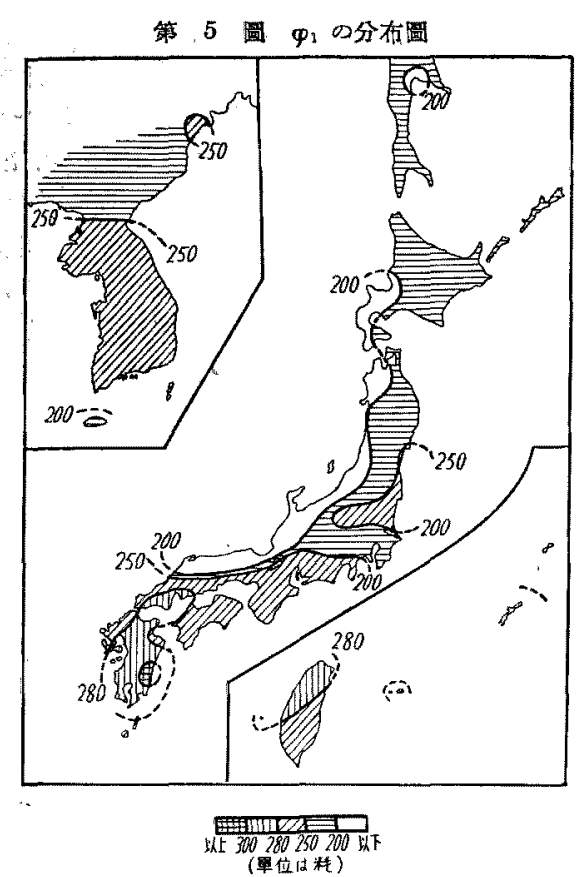

圖の如く高緯度に行くに従つて小さくなる，大體緯度 と平行して變つてるるが臺灣より內地に進む際に石垣 島, 那螼に極小點が出來, 宫崎, 鹿兒島で急に上鼠し それより激次下降する。

$a_{1}$ と $\varphi_{1}$ との關係は第 4 䁅の如くで, 臺灣と北陸, 東北地方の日本海側の地方が特に目立つ. 荗りの內地 及び朝鮮は一般に $a_{1}$ 小さくなるにつれ $\varphi_{1}$ が減少す

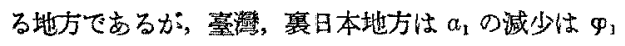
の增加となつてるる. 北海道, 櫵太は $\varphi_{1}$ の值のみ異 り南程小さく $a_{1}$ は大體似通つた值である。

次に最大降雨侍期の進行狀態は $\varphi_{1}$ の值の分布第 5 圖之第 4 圖上り分かる樣に臺灣と裹日本とでは南から 北に進み，北海道，櫵太好體南上り北へ進み，殘り の冈地及び朝鮮は大體北上り南下寸ることがかかる。

\section{5. 牛年嵁化}

坐年變化の振幅 $a_{2}$ の最大值は，年變化同樣臺灣に 見られる. 丙地唍全に表日本と赛日本に分けられ， 前者の値が大，後者が小て，北上するにつれて小くな る. 朝鮮では日本海側が黄海側より大きい. 特に中部 朝鮮地方が最大である。内地では銚子の如き $a_{2}$ が $a_{1}$ 吙り大きいといふ例外の場合するる.
位相角 $\varphi_{3}$ は $\varphi_{1}$ と区則に表日本地方が窝日本地方 より大きい， $a_{9}, \varphi_{2}$ の關係より全體を大凡 2 つに分け られる. $9_{2}$ が $80^{\circ}$ 附近の地方と. $300^{\circ}$ 附近の地方と である。，前荅は一般に $a_{3}$ は大きく，壹灣の西牛分，

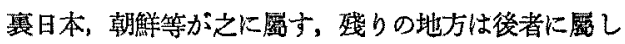
概して

\section{§6. 4 ケ月變化}

4 ケ月孌化の振幅 $a_{8}$ は一般に小さい，全國的には 京城，名瀨が最大である．概して表日本，中部朝鮮地方 は大きく，他はこれを中心として漸次小さくなつてる る．䁷灣は大きくはない，位相觕 $\varphi_{3}$ は襄日本地方が 表日本地方よりも大で，朝鮮でも日本海側が黃海侧よ

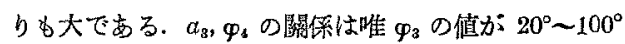
間に多く分散し $80^{\circ}$ 附近が一番多い事位しか分らな i.

§7. $\frac{1}{4}$ 年 (3 ケ月) 及び $\frac{1}{5}$ 年 $(2.4$ ケ月) 整化

第 1 表文び既连のことより明らかな如く降水量の調 和解析の結果では 3 ケ月變化及ぴ 2.4 ケ月變化の振 踾 $a_{4}$ 及び $a_{5}$ が $a_{2}, a_{3}$ に较べ大きい地方がする，a。 は九州，四國の南坐部は大きい方て北上するにつれ減 少する、朝鮮では中部地方が大きい， $a_{6}$ む同樣なこと が云へる. しかし $\varphi_{4}, \varphi_{5}$ の分布は餘り刵然としない。 $a_{4}, \varphi_{4}$ 圆よb大體梅雨期に降水量多い地方は $\varphi_{4}$ が $180^{\circ}$ 附近に集中し, 梅雨期の降水量方多い程 $a_{4} b$ 大 きい， $a_{5}, \varphi_{5}$ 圆より $a_{3}$ は $\varphi_{5} か ゙ ~ 340^{\circ}$ 附近に一番大 でこれを中心として濑次減少してるる。

\section{§8. 最大隆水量の起生月}

年變化の項より最多降水量の远生月を゙算出すれば, 本邦の大部分の地方は 6,7 月で，赛日本地方とその樣 子が大變異る。一般に內地, 朝鮮では北程早く起る. 樺太では5 月中に起る。

筫際罠多降水量の起生月は 9 月が多く、6月が之に

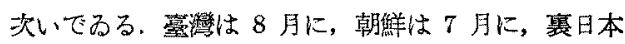
地方は 12 月に多い。此等を上の年變化の頃のみより の計算值と比較すると相當哙違が見られる。

更に牛年, $\frac{1}{3}, \frac{1}{4}, \frac{1}{5}$ 年變化等の大體の極大惟の起 生月日を各 $a \varphi$ 圖加ら求める。橫軸比極大値の起生 月日をとり，縱軸にaをとり各 $a$ の桠值起生の月日 を圖示すれば第 6 圆の椂である. 年變化較差 $a_{1}$ 中

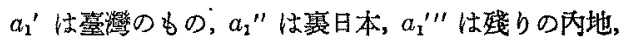
朝㶍のものを示す。此國を見れば7 月には $a_{1}{ }^{\prime \prime \prime} の 一$ 部， $a_{n}, a_{5}$ の 3 つの變化の極大值が集つてるる.從つ 


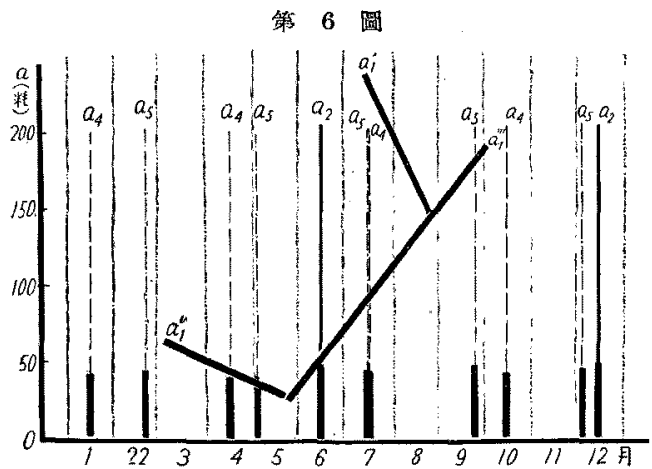

極大值起生月日

て 7 月には雨が多い. 叉 $a_{1}{ }^{\prime \prime \prime}$ の一部と $a_{4}$ とがある

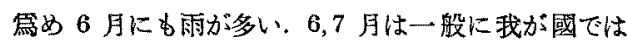
梅雨に虽する. 次に分るのは 9 月の降雨であり，又 襄日本の 4 月の降雨である. 此の行き方で進めば惯 際一年に 2 包山があらはれるのすよく說明がつくと 思交.

\section{§9. 梅雨との關係}

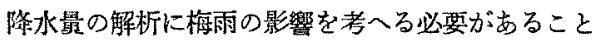
は各變化の極大降水量起生月が 7 月に最多く現れ, 夫に次て 6 月にも集ることによつても分る.

年振幅 $a_{1}$ と6月の降水量とを較べて見れば大體直
線的閵係になつてるる. 6 月の量が少い程 $a_{1}$ ஆ小さ い. 7 月の雨量との關係も同樣となる, 更に6,7月の

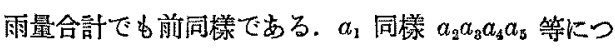
いて調べたが黨灣，沛繩を除けば $a_{1}$ と $a_{4}$ 及び $a_{5}$ と が大體 6,7 月の雨量合計したるのと關係がある.勿諭 內地の梅雨は 6 月から 7 月にかけて起る梅雨期の降 水量少ない地方は $a_{1} \cdots a_{5}$ の值が小さくなつてるる, 之に依つて梅雨には $a_{1}, a_{4} a_{5}$ と一番多く關係があり， 場所加云へば \& 3 で述へた， $I_{1}, I I I_{a}$ が主要地方 であることが分る。

\section{$\S 10$ 結 語}

本邦の降水量の年變化樣式を示さんが感め 76 の測 候所の絮年本均降水量の調和解析を行つた. 先つ $a_{0} a_{1}$ $\cdots a_{5}, \varphi_{1} \cdots \varphi_{5}$ 索計算し， $a_{1} \cdots a_{3}$ の值の比較の ため $a_{2} / a_{1}, a_{3} / a_{1}, a_{4} / a_{1}, a_{3} / a_{1}$ を算出し, その大小に より 7 つの型に分類し，それの地理的分布を調へ又 $a_{1} \cdots a_{5}, \varphi_{1} \cdots \varphi_{5}$ の地理的分布, 更に $a$ と $\varphi$ と

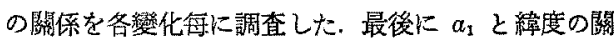
係や極值起生月或は又梅雨量との閶係家調へ， $a_{4}, a_{5}$ が降水量では無視出來ない位大なる影響があることを 知方。

最後に御留篤なる御指導と本文の御校閱を賜つた築 地先生一御禮を电しすゲる。(昭和 13 年6月）

第 1 表

(a)

\begin{tabular}{|c|c|c|c|c|c|c|c|c|c|c|c|c|}
\hline 湘候所 & $\begin{array}{c}\mid \text { 統計 } \\
\text { 開始年 }\end{array}$ & $a_{0}$ & $a_{1}$ & $\alpha_{2}$ & $a_{3}$ & $a_{4}$ & $a_{5}$ & $\varphi_{1}$ & $\varphi_{2}$ & $\varphi_{3}$ & $\varphi_{4}$ & $\varphi_{5}$ \\
\hline 春 & 1897 & 18063 & $240 \cdot 62$ & 7316 & $13: 62$ & $14 \cdot 76$ & 21.09 & 25904 & 60.80 & $215 \cdot 57$ & 2065 & $121 \cdot 57$ \\
\hline 南 & 1897 & $141^{*} 43$ & 184.45 & 85.78 & 15.58 & 2285 & $24: 13$ & 27297 & 81.50 & 93860 & 287.76 & $269 \cdot 16$ \\
\hline 湖 & 1897 & $81 \cdot 35$ & $78 \cdot 39$ & 26.26 & 976 & $5 \cdot 18$ & 540 & 28286 & 7052 & 21033 & 266.90 & 43.43 \\
\hline 中 & 1897 & 14260 & 15338 & 5289 & $6: 37$ & 29.06 & 21.62 & $289 \cdot 10$ & 7260 & $185 \cdot 90$ & $290 \cdot 40$ & 9075 \\
\hline 壱 北 & 1897 & 17992 & $97 \cdot 16$ & $39 \cdot 43$ & 10.99 & 14.95 & 11.99 & $286 \cdot 35$ & $281 \cdot 43$ & $81 \cdot 89$ & 12036 & $87 \cdot 44$ \\
\hline 石垣島 & 1897 & 17968 & 53.03 & 6.65 & $21 \cdot 89$ & $9 \cdot 05$ & 780 & 23600 & 286.78 & 7226 & $241 \cdot 60$ & $231 \cdot 35$ \\
\hline 㵜 & 1891 & & $61 \cdot 25$ & & $17 \cdot 81$ & 21.01 & $21^{\circ}$ & & & & & 106.95 \\
\hline 瀨 & 1897 & 256 & 7230 & 19.94 & $42 \cdot 14$ & $19 \cdot 26$ & 29.58 & $279 \cdot 27$ & $211 \cdot 46$ & $33 \cdot 50$ & $271 \cdot 81$ & $82 \cdot 85$ \\
\hline 鹿兒岛 & 1886 & $178 \cdot 48$ & $115 \cdot 17$ & 2017 & $21 \cdot 21$ & 3867 & $31 \cdot 60$ & 291.59 & $145 \cdot 75$ & 346.90 & 18080 & $11 \cdot 20$ \\
\hline & 1886 & & $127^{\circ}$ & & 247 & $35 \cdot 42$ & 23 & 30 & 301 & 32 & 194.50 & 21.75 \\
\hline 本 & 1891 & 1546 & $104 \cdot 12$ & $29:$ & .2785 & 3 & 23 & & $12 \mathrm{~L} \cdot 35$ & 319 & & 780 \\
\hline & 1891 & 145.44 & 10639 & 18.49 & 1873 & $35 \cdot 16$ & $30 \cdot 10$ & $285 \cdot 00$ & $107 \cdot 40$ & 27617 & $167 \cdot 40$ & 34970 \\
\hline & 1886 & & & & $10 \cdot 6$ & & & & 118 & & & $358 \cdot 10$ \\
\hline & 1887 & $186 \cdot 84$ & $124: 55$ & 15.81 & 760 & 45.03 & $45-43$ & 27650 & 5295 & 68.00 & 14470 & $351 \cdot 25$ \\
\hline & 1890 & & & 17 & 14 & & 25 & 276 & 89 & 321 & & 339.45 \\
\hline & 1887 & $133 \cdot 46$ & 84 & $10 \cdot 60$ & 16.00 & 26. & 16.21 & $272 \cdot 18$ & 333.75 & 330 & 173.70 & $331 \cdot 27$ \\
\hline & 1886 & $133 \cdot 58$ & $78 \cdot 05$ & $17 \cdot 44$ & $20 \cdot 37$ & 3394 & $24: 89$ & $285 \cdot 78$ & $127 \cdot 30$ & $339 \cdot 55$ & 16870 & $339 \cdot 15$ \\
\hline 賉 & 1886 & $124 \cdot 18$ & & 7 & $13 \cdot 97$ & 30 & 2632 & $286 \cdot 31$ & 22030 & 359 & 16470 & 34200 \\
\hline & 1891 & $90 \cdot 15$ & 51.09 & $7 \cdot 18$ & $12 \cdot 22$ & 1962 & 14.08 & $274: 25$ & 286.92 & $17 \cdot 10$ & 178.05 & $341 \cdot 10$ \\
\hline & 1890 & $109 \cdot 20$ & 56.03 & 855 & & 9.7 & & & & & & \\
\hline & 893 & & & 13. & 14. & 22 & 16 & & & & & 32744 \\
\hline & 1892 & 138.94 & 89. & $37 \cdot 26$ & 2495 & 250 & 19 & & & & & 326.53 \\
\hline & 1886 & $211 \cdot 75$ & $122 \cdot 39$ & $27 \cdot 27$ & 2307 & 3174 & $27 \cdot 35$ & $272 \cdot 63$ & 310.43 & $93 \cdot 73$ & 190.25 & $347 \cdot 75$ \\
\hline
\end{tabular}




\begin{tabular}{|c|c|c|c|c|c|c|c|c|c|c|c|c|}
\hline $\begin{array}{l}\text { 神 户 } \\
\text { 留 } \\
\text { 和歌山 }\end{array}$ & $\begin{array}{l}1897 \\
1886 \\
1886\end{array}$ & $\begin{array}{l}107 \cdot 85 \\
110 \cdot 60 \\
122 \cdot 85\end{array}$ & $\begin{array}{l}60 \cdot 25 \\
55 \cdot 53 \\
6 \cup \cdot 04\end{array}$ & $\begin{array}{l}13 \cdot 76 \\
17.70 \\
20.45\end{array}$ & $\begin{array}{l}14 \cdot 27 \\
14 \cdot 25 \\
17 \cdot 44\end{array}$ & $\begin{array}{l}22.43 \\
21 * 29 \\
23.21\end{array}$ & $\begin{array}{l}17 \cdot 82 \\
16.97 \\
19.29\end{array}$ & $\begin{array}{l}2 f 9 \cdot 12 \\
273 \cdot 86 \\
250 \cdot 18\end{array}$ & $\begin{array}{l}384 \cdot 45 \\
272 \cdot 01 \\
279 \cdot 82\end{array}$ & $\begin{array}{l}32 \cdot 36 \\
21 \cdot 60 \\
79 \cdot 95\end{array}$ & $\begin{array}{l}180 \cdot 10 \\
136 \cdot 62 \\
180 \cdot 00\end{array}$ & $\begin{array}{r}0880 \\
355 \cdot 30 \\
35 \% 35\end{array}$ \\
\hline 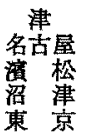 & $\begin{array}{l}1890 \\
1891 \\
1886 \\
1886 \\
1886\end{array}$ & $\begin{array}{l}145.94 \\
135.93 \\
15904 \\
159.57 \\
130.20\end{array}$ & $\begin{array}{l}79 \cdot 20 \\
59 \cdot 10 \\
82.96 \\
74 \cdot 45 \\
53 \cdot 99\end{array}$ & $\begin{array}{l}33.33 \\
30.07 \\
35.02 \\
32.23 \\
36.84\end{array}$ & $\begin{array}{l}25 \cdot 43 \\
14.97 \\
17.01 \\
12.98 \\
20 \cdot 11\end{array}$ & $\begin{array}{l}27 \cdot 73 \\
1249 \\
25 \cdot 03 \\
19 \cdot 85 \\
17 \cdot 22\end{array}$ & $\begin{array}{r}18 \cdot 99 \\
28 \cdot 64 \\
17 \cdot 44 \\
14 \cdot 00 \\
8 \cdot 08\end{array}$ & $\begin{array}{l}257 \cdot 89 \\
265 \cdot 59 \\
268 \cdot 47 \\
2 f 2 \cdot 99 \\
246 \cdot 07\end{array}$ & $\begin{array}{l}303 \cdot 82 \\
224 \cdot 96 \\
291 \cdot 10 \\
307 \cdot 24 \\
287 \cdot 19\end{array}$ & $\begin{array}{l}58 \cdot 00 \\
53 \cdot 78 \\
78 \cdot 71 \\
81 \cdot 80 \\
57 \cdot 80\end{array}$ & $\begin{array}{l}197 \cdot 85 \\
358 \cdot 20 \\
197 \cdot 75 \\
185 \cdot 50 \\
191 \cdot 60\end{array}$ & $\begin{array}{r}1.80 \\
312.97 \\
35490 \\
070 \\
290.12\end{array}$ \\
\hline 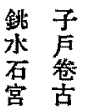 & $\begin{array}{l}1888 \\
1897 \\
1888 \\
1886\end{array}$ & $\begin{array}{r}135 \cdot 92 \\
120 \cdot 65 \\
93 \cdot 35 \\
111 \cdot 92\end{array}$ & $\begin{array}{l}26 \cdot 44 \\
5 * \cdot 17 \\
46 \cdot 29 \\
53 \cdot 99\end{array}$ & $\begin{array}{l}48 \cdot 32 \\
35 \cdot 36 \\
20 \cdot 14 \\
29 \cdot 88\end{array}$ & $\begin{array}{l}24 \cdot 96 \\
34 \cdot 14 \\
10 \cdot 47 \\
18 \cdot 13\end{array}$ & $\begin{array}{r}14: 86 \\
10^{4} 47 \\
7 \cdot 56 \\
8: 38\end{array}$ & $\begin{array}{l}3 \cdot 24 \\
5.65 \\
69 \cdot 1 \\
5 \cdot 33\end{array}$ & $\begin{array}{l}228 \cdot 10 \\
255 \cdot 52 \\
255 \cdot 30 \\
238 \cdot 89\end{array}$ & $\begin{array}{l}277 \cdot 64 \\
289 \cdot 04 \\
3111 \cdot 45 \\
324 \cdot 50\end{array}$ & & $\begin{array}{l}143 \cdot 57 \\
167 \cdot 30 \\
1 \cdot 0 \cdot 90 \\
186 \cdot 94\end{array}$ & $\begin{array}{l}248 \cdot 83 \\
315 \cdot 77 \\
005 \cdot 10 \\
341 \cdot 15\end{array}$ \\
\hline 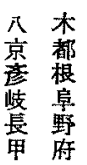 & $\begin{array}{l}1897 \\
1 \& 86 \\
1894 \\
1886 \\
1889 \\
1095\end{array}$ & $\begin{array}{r}11698 \\
128: 36 \\
137 \cdot 46 \\
161.19 \\
81.22 \\
102.69\end{array}$ & $\begin{array}{l}62 \cdot 72 \\
71 \cdot 10 \\
40 \cdot 26 \\
91 \cdot(9 \\
39 \cdot 64 \\
62 \cdot 40\end{array}$ & $\begin{array}{r}10.59 \\
752 \\
7.93 \\
14.74 \\
9.28 \\
26.22\end{array}$ & $\begin{array}{r}18 \cdot 93 \\
12 \cdot 44 \\
16 \cdot 57 \\
11 \cdot 18 \\
5 \cdot 24 \\
14 \cdot 10\end{array}$ & $\begin{array}{l}26 \cdot 18 \\
22 \cdot 02 \\
27 \cdot 93 \\
27 \cdot 40 \\
11 \cdot 89 \\
14 \cdot 00\end{array}$ & $\begin{array}{r}20 \cdot 22 \\
18 \cdot 50 \\
21 \cdot 6 ? \\
23 \cdot 01 \\
12 \cdot 49 \\
8 \cdot 98\end{array}$ & $\begin{array}{l}261 \cdot 6 \\
275 \cdot 10 \\
264 \cdot 71 \\
274 \cdot(77 \\
256 \cdot 43 \\
243 \cdot 33\end{array}$ & $\begin{array}{r}314 \cdot 10 \\
284-31 \\
30 \cdot 90 \\
288 \cdot 67 \\
44 \cdot 50 \\
331 \cdot 55\end{array}$ & $\begin{array}{l}12 \cdot 10 \\
15 \cdot 25 \\
43 \cdot 45 \\
61 \cdot 60 \\
46 \cdot 90 \\
78 \cdot 17\end{array}$ & & $\begin{array}{l}341 \cdot 40 \\
35 \% 55 \\
335 \cdot 60 \\
337 \cdot 00 \\
309 \cdot 43 \\
34 \% \cdot 10\end{array}$ \\
\hline 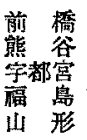 & $\begin{array}{l}1897 \\
1897 \\
1891 \\
1890 \\
1890\end{array}$ & $\begin{array}{r}105.09 \\
107.04 \\
129.04 \\
99.60 \\
99.73\end{array}$ & $\begin{array}{l}89 \cdot 60 \\
66 \cdot 03 \\
93 \cdot 70 \\
56 \cdot 01 \\
29 \cdot 26\end{array}$ & $\begin{array}{l}24.88 \\
29.89 \\
23.49 \\
21.16 \\
1672\end{array}$ & $\begin{array}{r}11.99 \\
17.92 \\
8.62 \\
10 \cdot 27 \\
9.07\end{array}$ & $\begin{array}{r}11 \cdot 81 \\
9 \cdot 85 \\
9 \cdot 67 \\
11 \cdot 48 \\
7 \cdot 28\end{array}$ & $\begin{array}{l}9 \cdot 47 \\
5.46 \\
8.78 \\
7 \cdot 19 \\
4 \cdot 77\end{array}$ & $\begin{array}{l}254 \cdot 60 \\
24 \cdot 82 \\
261 \cdot 12 \\
246 \cdot 30 \\
222 \cdot 40\end{array}$ & $\begin{array}{r}356 \cdot 75 \\
3 * 4 \cdot 47 \\
343 \cdot 0 \\
344 \cdot 10 \\
62.52\end{array}$ & & & $\begin{array}{l}334 \cdot 25 \\
328 \cdot 40 \\
: 44 \cdot 40 \\
318.70 \\
290.00\end{array}$ \\
\hline 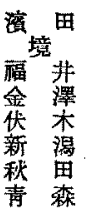 & $\begin{array}{l}1893 \\
1886 \\
1897 \\
1886 \\
1886 \\
1886 \\
1886 \\
1886\end{array}$ & $\begin{array}{l}138.24 \\
159.86 \\
197.77 \\
20.73 \\
179.72 \\
145.70 \\
147.03 \\
120.54\end{array}$ & $\begin{array}{l}34 \cdot 50 \\
26 \cdot 18 \\
54 \cdot 81 \\
62 \cdot 53 \\
57 \cdot 95 \\
47.13 \\
46 \cdot 34 \\
36 \cdot 93\end{array}$ & $\begin{array}{r}4 \cdot 98 \\
15 \cdot 40 \\
40 \cdot 13 \\
29 \cdot 81 \\
36 \cdot 48 \\
18 \cdot 13 \\
2.44 \\
17.50\end{array}$ & $\begin{array}{r}8.96 \\
13.56 \\
21.85 \\
13.57 \\
17.47 \\
6773 \\
11.42 \\
4.78\end{array}$ & $\begin{array}{r}27 \cdot 70 \\
27 \cdot 13 \\
24 \cdot 83 \\
21.37 \\
23 \cdot 20 \\
14 \cdot 47 \\
1 \cdot 82 \\
3 \cdot 05\end{array}$ & $\begin{array}{r}20 \cdot 58 \\
18 \cdot 18 \\
23 \cdot 07 \\
19 \cdot 87 \\
17 \cdot 73 \\
12 \cdot 6 \\
8 \cdot 96 \\
9 \cdot 04\end{array}$ & $\begin{array}{l}261 \cdot 84 \\
158 \cdot 90 \\
12674 \\
185.70 \\
134 \cdot 83 \\
155 \cdot 05 \\
201 \cdot 05 \\
158 \cdot 60\end{array}$ & $\begin{array}{r}75 \cdot 45 \\
69 \cdot 59 \\
113 \cdot 64 \\
13677 \\
113830 \\
127 \cdot 42 \\
111 \cdot 40 \\
88 \cdot 85\end{array}$ & $\begin{array}{r}25 \cdot 25 \\
75 \cdot 90 \\
118 \cdot 80 \\
18 \% \cdot 80 \\
168 \cdot 25 \\
197 \cdot 05 \\
224 \cdot 90 \\
189 \cdot 50\end{array}$ & & $\begin{array}{l}345 \cdot 60 \\
337 \cdot 05 \\
305 \cdot 88 \\
317 \cdot 33 \\
307 \cdot 30 \\
326 \cdot 45 \\
339 \cdot 10 \\
312 \cdot 60\end{array}$ \\
\hline 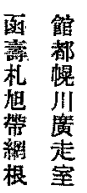 & $\begin{array}{l}1886 \\
1889 \\
1886 \\
1889 \\
1892 \\
1890 \\
1886\end{array}$ & $\begin{array}{r}88 \cdot 40 \\
101 \cdot 89 \\
86 \cdot 06 \\
89 \cdot 47 \\
79 \cdot 33 \\
67 \cdot 44 \\
80 \cdot 78\end{array}$ & $\begin{array}{l}43 \cdot 25 \\
42 \cdot 55 \\
31 \cdot 90 \\
41 \cdot 05 \\
44 \cdot 05 \\
23 \cdot 76 \\
39.98\end{array}$ & $\begin{array}{r}11.58 \\
6.66 \\
5.98 \\
4.40 \\
15.34 \\
8.72 \\
15.18\end{array}$ & $\begin{array}{l}2 \cdot 70 \\
3 \cdot 38 \\
3 \cdot 87 \\
6 \cdot 87 \\
8 \cdot 32 \\
6 \cdot 07 \\
6 \cdot 49\end{array}$ & $\begin{array}{l}7 \cdot 14 \\
4 \cdot 89 \\
190 \\
5 \cdot 10 \\
5 \cdot 69 \\
3 \cdot 13 \\
5 \cdot 55\end{array}$ & $\begin{array}{l}9 \cdot 97 \\
6.62 \\
3.33 \\
5.60 \\
1.95 \\
1.85 \\
5.69\end{array}$ & $\begin{array}{l}23 \cdot 26 \\
165 \cdot 20 \\
186 \cdot 90 \\
205 \cdot 45 \\
243 \cdot 90 \\
223 \cdot 70 \\
240 \cdot 49\end{array}$ & $\begin{array}{r}20 \cdot 55 \\
340 \cdot 05 \\
341 \cdot 15 \\
36 \cdot 00 \\
318 \cdot 45 \\
359 \cdot 55 \\
306 \cdot 25\end{array}$ & & $\begin{array}{l}120 \cdot 50 \\
253 \cdot 85 \\
261.23 \\
237 \cdot 62 \\
241 \cdot 20 \\
184 \cdot 05 \\
206 \cdot 90\end{array}$ & $\begin{array}{r}328 \cdot 47 \\
318 \cdot 25 \\
339 \cdot 95 \\
308 \cdot 22 \\
28 \cdot 50 \\
51 \cdot 12 \\
345 \cdot 40\end{array}$ \\
\hline 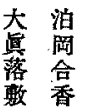 & $\begin{array}{l}1906 \\
1908 \\
1908 \\
1908\end{array}$ & $\begin{array}{l}59 \cdot 96 \\
69 \cdot 59 \\
70 \cdot 46 \\
62 \cdot 85\end{array}$ & $\begin{array}{l}37 \cdot 49 \\
35 \cdot 22 \\
37 \cdot 87 \\
39 \cdot 22\end{array}$ & $\begin{array}{r}6.18 \\
11.97 \\
8.09 \\
876\end{array}$ & $\begin{array}{l}4.00 \\
5 \cdot 21 \\
4 \cdot 95 \\
5.55\end{array}$ & $\begin{array}{l}0.35 \\
7 \cdot 42 \\
1 \cdot 81 \\
3 \cdot 74\end{array}$ & $\begin{array}{l}3 \cdot 80 \\
1 \cdot 77 \\
2 \cdot 67 \\
5 \cdot 86\end{array}$ & $\begin{array}{l}239 \cdot 00 \\
221 \cdot 73 \\
230 \cdot 00 \\
252 \cdot 83\end{array}$ & $\begin{array}{l}273 \cdot 71 \\
257 \cdot 95 \\
271 \cdot 07 \\
319 \cdot 60\end{array}$ & & $\begin{array}{r}228 \cdot 50 \\
281 \cdot 66 \\
28 \cdot 25 \\
286 \cdot 71\end{array}$ & $\begin{array}{l}305: 62 \\
297 \cdot 28 \\
200 \cdot 10 \\
184 \cdot 45\end{array}$ \\
\hline 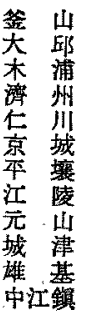 & $\begin{array}{l}1905 \\
1908 \\
1905 \\
1924 \\
1905 \\
1908 \\
1908 \\
1912 \\
1905 \\
1906 \\
1915 \\
1915\end{array}$ & $\begin{array}{r}117 \cdot 90 \\
82.05 \\
88 \cdot 48 \\
114 \cdot 66 \\
85 \cdot 46 \\
103.50 \\
85 \cdot 00 \\
106 \cdot 92 \\
111.32 \\
57 \cdot 04 \\
64 \cdot 65 \\
66 \cdot 28\end{array}$ & $\begin{array}{r}105 \cdot 17 \\
82.61 \\
72.45 \\
82 \cdot 34 \\
92.93 \\
117.71 \\
72.04 \\
74.08 \\
110.67 \\
53.76 \\
75.40 \\
73.89\end{array}$ & $\begin{array}{l}26 \cdot 83 \\
32 \cdot 27 \\
26 \cdot 80 \\
49 \cdot 60 \\
44 \cdot 04 \\
63 \cdot 59 \\
55 \cdot 88 \\
4388 \\
52 \cdot 44 \\
17 \cdot 84 \\
22 \cdot 10 \\
26 \cdot 68\end{array}$ & $\begin{array}{r}12 \cdot 98 \\
16 \cdot 05 \\
15 \cdot 03 \\
24.74 \\
33 \cdot 99 \\
47 \cdot 81 \\
23 \cdot 28 \\
23 \cdot 99 \\
32 \cdot 67 \\
13 \cdot 04 \\
9 \cdot 16 \\
12 \cdot 90\end{array}$ & $\begin{array}{r}23 \cdot 04 \\
7 \cdot 31 \\
7 \cdot 09 \\
19 \cdot 47 \\
19 \cdot 04 \\
28 \cdot 38 \\
29 \cdot 91 \\
6: 38 \\
17 \cdot 18 \\
9 \cdot 51 \\
981 \\
7 \cdot 71\end{array}$ & $\begin{array}{r}23 \cdot 69 \\
15 \cdot 69 \\
11 \cdot 55 \\
22 \cdot 91 \\
12 \cdot 6 \\
16 \cdot 78 \\
4.35 \\
14.03 \\
285 \\
2 \cdot 49 \\
8 \cdot 84 \\
4.54\end{array}$ & $\begin{array}{l}275 \cdot 27 \\
265 \cdot 95 \\
26: 46 \\
249 \cdot 10 \\
261 \cdot 85 \\
264 \cdot 18 \\
252 \cdot 65 \\
251 \cdot 00 \\
253 \cdot 00 \\
246 \cdot 16 \\
253 \cdot 50 \\
225 \cdot 00\end{array}$ & $\begin{array}{l}70 \cdot 92 \\
59 \cdot 21 \\
70 \cdot 00 \\
17 \cdot 40 \\
63 \cdot 36 \\
68 \cdot 44 \\
68 \cdot 84 \\
40 \cdot 30 \\
43 \cdot 80 \\
39 \cdot 20 \\
32 \cdot 95 \\
79 \cdot 78\end{array}$ & $\begin{array}{r}22 \cdot 79 \\
208 \cdot 30 \\
203 \cdot 95 \\
161 \cdot 85 \\
219 \cdot 63 \\
230 \cdot 20 \\
182 \cdot 25 \\
251 \cdot 80 \\
207 \cdot 90 \\
167 \cdot 80 \\
155 \cdot 00 \\
230 \cdot 35\end{array}$ & $\begin{array}{r}123 \cdot 61 \\
121.17 \\
94 \cdot 57 \\
242 \cdot 80 \\
46.67 \\
56 \cdot 52 \\
65.93 \\
31 \cdot 93 \\
8.35 \\
305 \cdot 23 \\
309 \cdot 95 \\
20.65\end{array}$ & $\begin{array}{r}328 \cdot 45 \\
331 \cdot 23 \\
205: 80 \\
344 \cdot 35 \\
274 \cdot 77 \\
273 \cdot 23 \\
104 \cdot 31 \\
30 \cdot 36 \\
348 \cdot 45 \\
4 \% \cdot 70 \\
135 \cdot 80 \\
215 \cdot 40\end{array}$ \\
\hline
\end{tabular}




\begin{tabular}{|c|c|}
\hline & 第 $\quad 2$ \\
\hline 類 別 & 候 \\
\hline$I(a)$ & 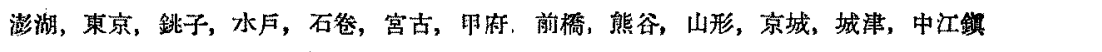 \\
\hline$I(b)$ & 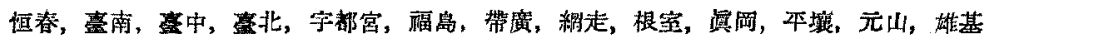 \\
\hline If & 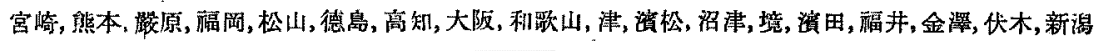 \\
\hline III $a)$ & 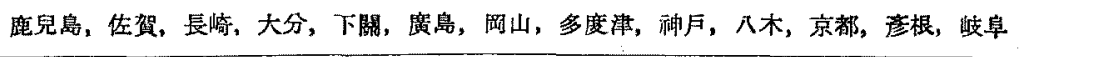 \\
\hline III b) & 那嘶 \\
\hline $\mathbb{N}$ & 名古屋, 青森, 札幌, 大泊, 落合, 票香, 大邱，木浦, 仁川, 江陵 \\
\hline $\mathrm{V}$ & 名瀨，秋田，旭川 \\
\hline VI & 春野, 函館, 僖都 \\
\hline VII & 石垣島 \\
\hline
\end{tabular}

紹 介

Ferdinand Steinhauser: Die Meteorologie des Sonnblicks (ゾンブリック山の氣 象). I. Teil, Wien, 1938.

1886 年 9 月 2 日から Sonnblick 山頂に於ける氣象 觀測所が開設せられてからすでに 50 年以上になり規 則正しい觀測が透行されて居る. Sonnblick ( $47^{\circ} 03^{\prime} \mathrm{N}$, 12 $2^{\circ} 57^{\prime}$ E) 觀测所の高さは $3106 \mathrm{~m}$ であつて，第一篇 に於ては 50 年間の觀測により Sonnblick 山頂の氣 象を述へてある. 性賀上，觀測値を平均した平均值の 表が多い，氣温，濕度，雲量と日照, 降水量, 風向飞

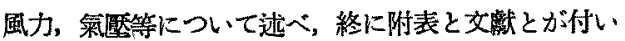
て居る. 第 2 篇には. Sonnblick 山附近に於ける氣象 事象に關する記述をする積りだと言ふ。(范川秀俊)

\section{H, R. Byers: Synoptic and Aeronautical} Meteorology (像報及航空氣衰學). New York and London, 1937.

如何にもアメリカ人の書いたやらな本である. 第一 に良いと信ずる學說だけを舉げて極力推獎して居るこ
とである．探るに足ら双とか，文句家つけたいやうな ものには一切觸れて居ないことである.この點非常に 氣持がよい，第二にヨーロッパ臭味を脫して，漸く㯰 自の境地を開拓して來た新しいアメリカの氣象學が述 べてあることである. Rossby 等の Massachusetts 派の學說が稆介されて居る．新しい氣塊論の理念が全 哭を貫いて居るのである.

飛行機の操縱者や氣象學の學生向きに air-mass analysis system を知らしめるために書かれたすので あつて，賽用になるものを主として述べてあると著者 は言つて居る.

內容は次ぎの 15 章から成る。

緒言，1. 輻射と太氣中に拉りる溫度の分布，2. 安 定度，不安定度と垂直運動，3．氣塊，其の特性と變

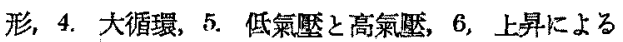
氣塊の變化，7. 北アカリカの各氣塊，8. 天氣圖の氣 塊分析，9. 天氮预報，10. 凝結と降水，11. 霧，12. 雷雨, トルネードー及龍姿，13，航空機に對する着氷，

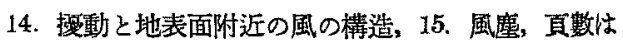
279 頁, 型恃菊版, 偠は約 13 圆. (荒川唀俊) 